Reprod. Nutr. Dévelop., 1986, 26 (6), 1281-1288.

\title{
Plasma free and total iodothyronine levels in the newborn lamb. \\ Physiological considerations
}

\author{
G. CABELLO, Chantal WRUTNIAK
}

Laboratoire des Maladies Métaboliques, I.N.R.A. Theix, 63122 Ceyrat, France.

\begin{abstract}
Summary. Neonatal changes in plasma total and free iodothyronine levels were monitored in 18 Limousin $\times$ Romanov suckling lambs (experiment 1) and 24 Limousin $\times$ Romanov animals bottle-fed in standardized conditions (experiment 2 ). In the two experiments, plasma free T3 levels were closely related to total T3 levels, whereas some differences could be observed between total and free plasma T4 levels. The neonatal rise in free T4 in particular was higher than that observed for total T4 levels. Consequently, the enhancement of T4 availability for T3-generating cells could partly explain the neonatal T3 surge. In addition, plasma reverse T3 levels decreased progressively during the first $48 \mathrm{~h}$ of life in suckling lambs. These results suggest also that hypotrophy and/or nutritional status could affect neonatal thyroid function : plasma active iodothyronine levels decreased sharply in bottle-fed lambs (birthweight : $2.29 \mathrm{Kg}$ ) compared to suckling ones (birthweight : $3.57 \mathrm{Kg}$ ), whereas reverse T3 levels increased.
\end{abstract}

\section{Introduction.}

Neonatal changes in plasma total iodothyronine levels have been studied intensively in the lamb. The major feature observed is the large increase in plasma total triiodothyronine (T3) levels during the first hours of life (Nathanielsz et al., 1973 ; Sack et al., 1974 ; Klein et al., 1978a ; Cabello and Levieux, 1980 ; 1981 ; Cabello and Wrutniak, 1984), occurring with (Nathanielsz et al., 1973 ; Fisher et al., 1977) or without (Cabello and Levieux, 1980, 1981 ; Cabello and Wrutniak, 1984) a rise in plasma total thyroxine (T4) levels.

However, the mechanisms that induce the neonatal surge of T3 are not fully understood. Since reverse T3 and free iodothyronine data are very scarce, we have studied neonatal changes in plasma total and free T4, total and free T3 and reverse T3 levels in lambs. Because nutritional status could affect neonatal thyroid function (Wrutniak, 1985), this study was performed using two experimental conditions : suckling and standardized bottle-feeding.

Material and methods.

Animals. - The first experiment was conducted with 18 newborn Limousin $x$ Romanov lambs (mean birthweight : $3.57 \pm 0.19 \mathrm{~kg}$ ) kept with the dams. In the 
second experiment, 24 animals of the same breed (mean birthweight : $2.29 \pm 0.40 \mathrm{~kg}$ ), removed from the dams, were given the same colostrum in amounts proportional to birthweight $(2.5 \%$ of the birthweight every $4 \mathrm{~h})$ for $36 \mathrm{~h}$. They then received an artificial milk diet ad libitum.

Blood sampling. - Two-ml blood samples were collected from a jugular vein into heparinized test tubes. Plasma was separated by centrifugation within 15 min and kept frozen at $-20^{\circ} \mathrm{C}$ until analysed.

Analytical methods. - T4, T3, reverse T3, free T4 and free T3 levels in plasma were measured by radioimmunoassay as previously described (Cabello and Levieux, 1980 ; Wrutniak and Cabello, 1985 ; Wrutniak et al., 1985). Hormone levels are presented as mean values with their SEM. Statistical analysis were carried out using the paired t-test and regression analysis (correlation coefficients).

\section{Results.}

Suckling lambs (fig. 1). - During the first $8 \mathrm{~h}$ of life, plasma total and free T4 levels rose significantly as did the plasma total and free T3 levels $(P<0.005$, $P<0.01, P<0.005$ and $P<0.005$, respectively). These increases occurred without alterations in the $\mathrm{T} 3 /$ free $\mathrm{T} 4$ ratio, but with a significant increment in the value of the free $T 4 / T 4$ ratio $(P<0.025)$.

After the first $8 \mathrm{~h}$ of life, free and total T4 levels decreased until $32 \mathrm{~h}$ (respectively $P<0.001$ and $P<0.025$ ). Total T4 reached values similar to those observed at birth, whereas free T4 values remained slightly high $(P<0.025)$. Plasma total and free T3 concentrations did not change after $8 \mathrm{~h}$ post partum, as did the value of the free T4/T4 ratio. However, the value of the T3/free T4 ratio increased significantly between 8 and $32 \mathrm{~h}$ after birth $(P<0.05)$.

From birth to $48 \mathrm{~h}$ post partum, plasma reverse T3 levels and the value of the reverse $T 3 /$ free $T 4$ ratio decreased sharply $(P<0.001)$.

During the neonatal period, the free T4 fraction accounted for 0.45 to 0.57 p. 1000 of the total hormone. This percentage was higher for free T3 2.2 to 2.9 p. 1000$)$.

Strong relationships between total and free T3 levels, and between total and free T4 levels were noted (table 1).

TABLE 1

Relationships between total and free iodothyronine levels in suckling lambs ( $\mathrm{r}$ values). ${ }^{* *}: \mathrm{P}<0.05$.

\begin{tabular}{rlc}
\hline $\begin{array}{c}\text { Age } \\
\text { (hrs) }\end{array}$ & $\begin{array}{c}\text { T4 and free T4 } \\
\text { relationships }\end{array}$ & $\begin{array}{c}\text { T3 and free T3 } \\
\text { relationships }\end{array}$ \\
\hline 0 & $0.677^{* *}$ & $0.936^{* *}$ \\
8 & 0.435 & $0.687^{* *}$ \\
16 & 0.404 & $0.806^{* *}$ \\
32 & $0.613^{* *}$ & $0.827^{* *}$ \\
48 & $0.672^{* *}$ & $0.651^{* *}$ \\
\hline
\end{tabular}



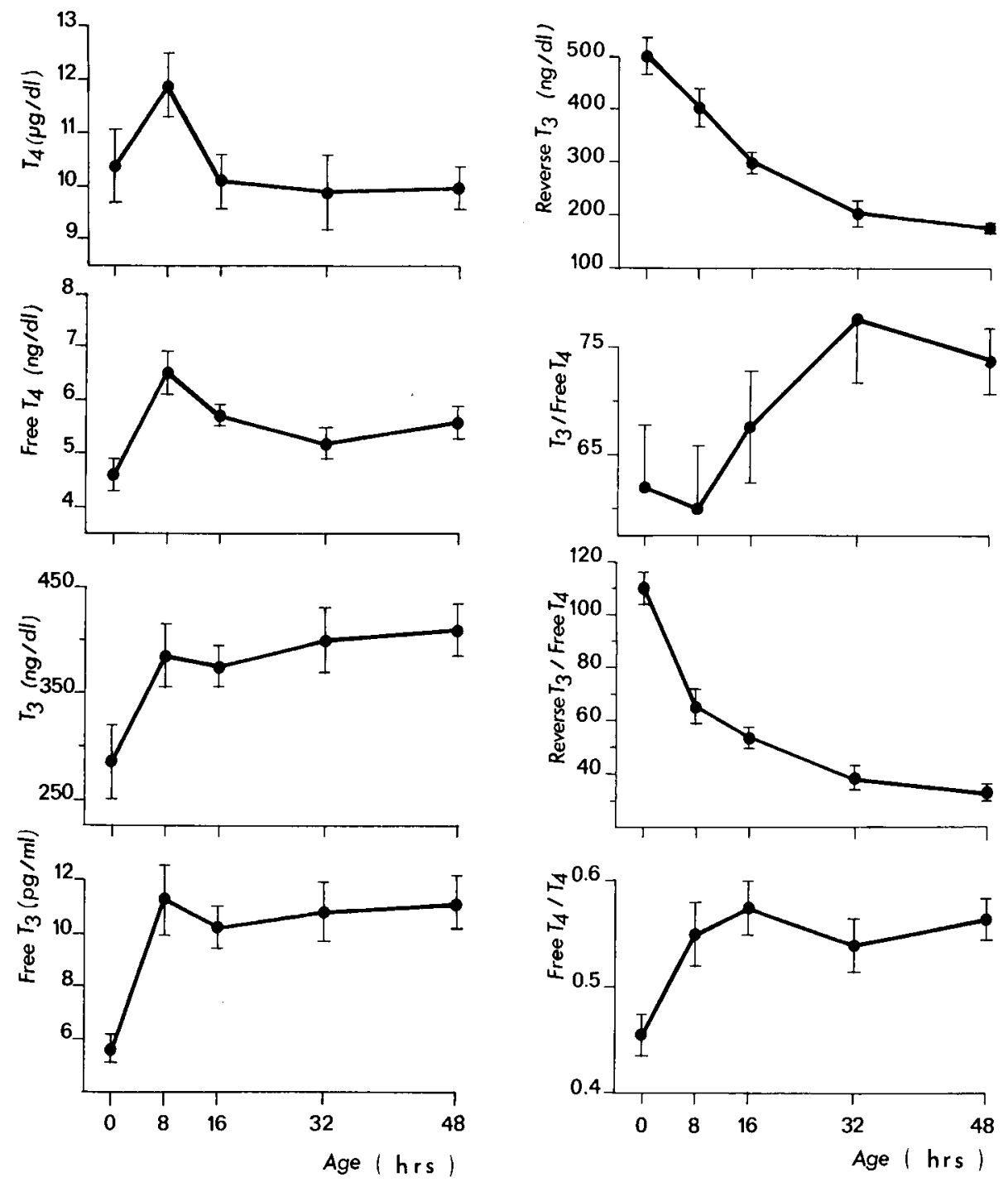

FIG. 1. - Neonatal changes in total and free iodothyronine levels in suckling lambs. 
Standardized bottle-fed lambs (fig. 2). - As observed in the previous experiment, plasma total and free T3 levels rose during the first $8 \mathrm{~h}$ of life $(P<0.001)$ without significant changes in the value of the T3/free T4 ratio, whereas plasma reverse T3 levels and the value of the reverse T3/free T4 ratio decreased $(P<0.001)$. Plasma total and free T4 levels rose during the first $4 \mathrm{~h}$ of life $(P<0.005$ and $P<0.001)$ with a significant increase in the values of the free T4/T4 ratio $(P<0.001)$.

After $8 \mathrm{~h}$ post partum, plasma total and free T4 and T3 decreased sharply until $24 h(P<0.001)$. So did the value of the $T 3 /$ free $T 4$ ratio $(P<0.001)$. Plasma reverse T3 levels and the value of the reverse T3/free T4 ratio rose simultaneously $(P<0.005$ and $P<0.001)$.

Thereafter, plasma levels of active iodothyronines increased progressively. However, 20 days post partum, total and free T3 and the value of the T3/free T4 ratio remained lower than the value observed at birth $(P<0.001)$. During the same period, plasma reverse T3 and the values of the reverse T3/free T4 ratio reached low levels.

In this experiment, strong relationships between total and free T3 levels and between total and free T4 were observed (table 2).

TABLE 2

Re/ationships between total and free iodothyronine levels in standardized bottle-fed lambs (r values). ${ }^{* *}: \mathrm{P}<0.05$.

\begin{tabular}{ccc}
$\begin{array}{c}\text { Age } \\
\text { (hrs) }\end{array}$ & $\begin{array}{c}\text { T4 and free T4 } \\
\text { relationships }\end{array}$ & $\begin{array}{c}\text { T3 and free T3 } \\
\text { relationships }\end{array}$ \\
\hline 0 & $0.871^{* *}$ & $0.952^{* *}$ \\
4 & $0.797^{* *}$ & $0.950^{* *}$ \\
8 & $0.828^{* *}$ & $0.896^{* *}$ \\
12 & $0.676^{* *}$ & $0.755^{* *}$ \\
16 & $0.634^{* *}$ & $0.924^{* *}$ \\
20 & $0.768^{* *}$ & \\
24 & $0.864^{* *}$ & \\
28 & $0.884^{* *}$ & \\
32 & $0.787^{* *}$ & $0.926^{* *}$ \\
36 & $0.588^{* *}$ & \\
48 & $0.744^{* *}$ & \\
\hline
\end{tabular}

\section{Discussion.}

Large differences could be observed in plasma iodothyronine levels between the two experiments. Firstly, plasma total and free T4 and T3 levels were much lower in the second (standardized bottle-fed lambs) than in the first (suckling lambs) experiment ; as we previously observed that plasma active iodothyronine levels were positively related to birthweight in the lamb (Cabello and Levieux, 1981 ; Wrutniak, 1985), this difference is not surprising (mean birthweight : 2.29 vs $3.57 \mathrm{~kg}$ ). Secondly, neonatal changes were not similar in the two experiments ; this could be due to different birthweights in the two groups of lambs, but also to 

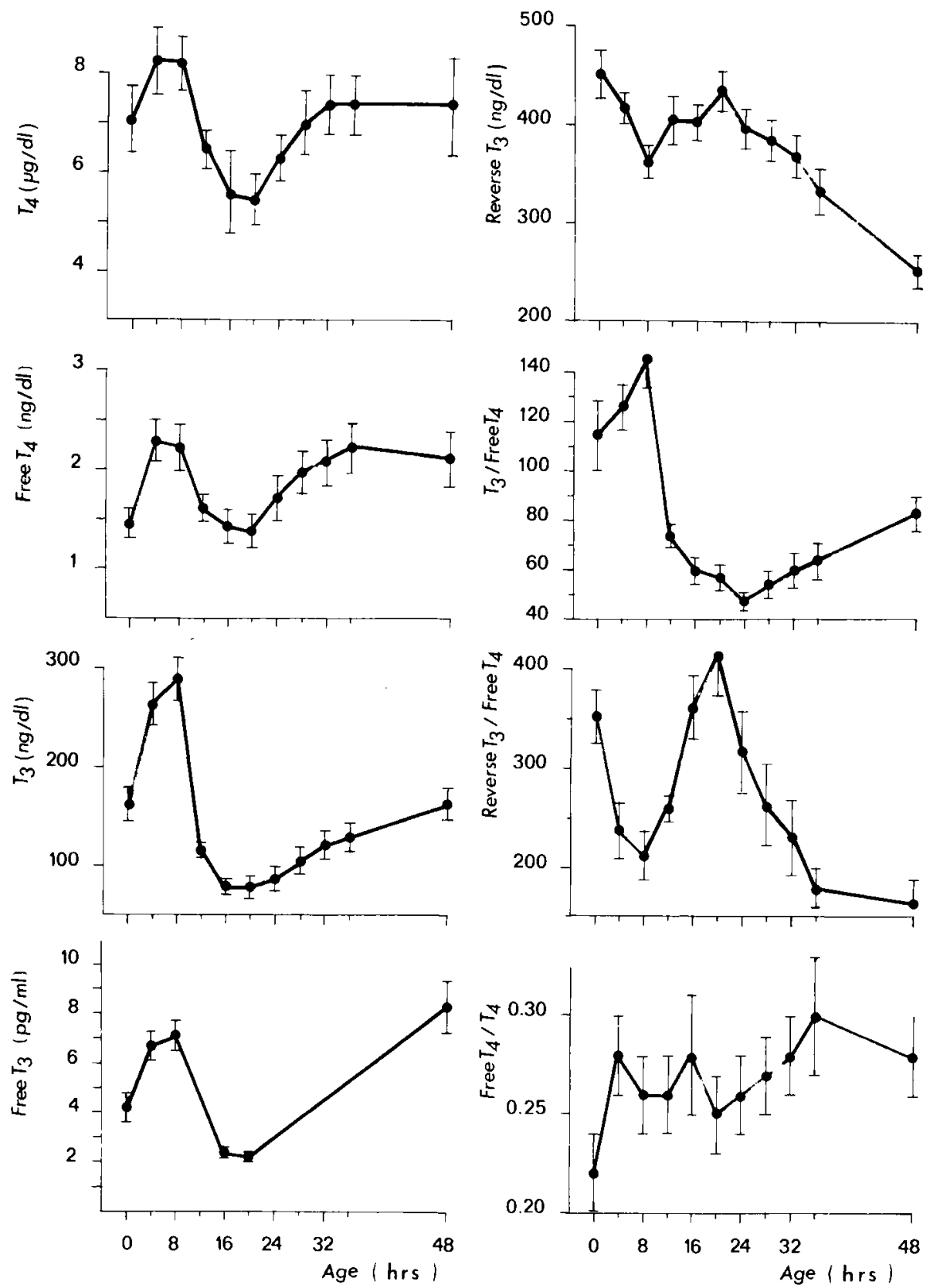

FIG. 2. - Neonatal changes in total and free iodothyronine levels in standardized bottle-fed lambs. 
the different nutritional schedules used : in our experimental conditions, colostrum bottle-feeding induced some degree of undernutrition (Wrutniak, 1985 ; Wrutniak and Cabello, 1986).

However, the present results give evidence that, whatever the nutritional status and birthweight, some important features of neonatal thyroid function are similar in newborn lambs.

- In both experiments, changes in plasma total and free T3 levels were parallel. Moreover, the strong relationships observed between total and free hormonal fractions suggest that the amount of total T3 was a major determinant of the amount of free T3. Some differences could be observed between changes in plasma free and total T4 levels; the neonatal rise of free T4 was greater than that of total T4; moreover, at $48 \mathrm{~h}$ post-partum, plasma free T4 levels were higher than the values observed at birth, whereas plasma total T4 levels were the same. The significant increase in the value of the free T4/T4 ratio during the first $8 \mathrm{~h}$ of life suggests that, during this period, carrier protein affinity or capacity for T4 was markedly reduced. According to the correlations observed, the free fraction seemed to depend less on the total fraction as concerns T4 than in the case of T3.

- The present results provide evidence that the neonatal rise in plasma T3 levels (Nathanielsz et al., 1973 ; Sack et al., 1974; Klein et al., 1978a ; Cabello and Levieux; 1980, 1981; Cabello and Wrutniak, 1984) occurs with a simultaneous increase in plasma T4 levels. However, the mechanisms involved in the T4 and T3 surges are probably quite different. As total thyroxinemia progressively returned to birth value after the initial increase, the neonatal TSH hypersecretion observed by Fisher et al. (1977) is probably the origin of the transient rise in total T4 levels. The neonatal plasma T3 surge is not fully understood, but some possible explanations have been reported. The TSH hypersecretion that occurs at birth (Fisher et al., 1977) could induce a preferential thyroidal T3 hypersecretion, as observed during iodine deficiency (Greer et al., 1968). However, in previous work (Wrutniak and Cabello, 1985), the peak T3 level was shown to occur before the peak T4 level after TSH administration in the newborn lamb. This does not agree with the neonatal changes. Moreover, Sack and Fisher (1975), Sack et al. (1975) and Fisher et al. (1977) have dissociated the increases in plasma TSH and T3 by preventing neonatal cooling (TSH unchanged, T3 raised) or delaying umbilical cord cutting (TSH raised, T3 unchanged). Another hypothesis, partly based on the observation of a rise in the value of the T3/T4 ratio, suggests that increased peripheral 5 '-deiodination of T4 could occur during the first hours of life (Sack et al., 1975 ; Fisher et al., 1977 ; Nathanielsz and Fisher, 1979). However, only free T4 enters the cells to generate T3, and no significant rise in the value of the T3/free T4 ratio has been observed. As the T3 surge closely parallelled the free T4 rise, the enhancement of T4 availability for the generating T3 cells could increase peripheral T3 production.

As mentioned above, changes in plasma iodothyronine levels after the 8 first hours of life are different between suckling and standardized bottle-fed lambs :

1) In suckling animals, the increase in the value of the T3/free T4 ratio between 8 and $32 \mathrm{~h}$ suggests that some changes occur in T3 metabolism. As the 
reverse T3/free T4 ratio simultaneously decreased, this period is probably important for the maturation of thyroid hormone metabolism, because $5^{\prime}$-deiodination seems to become a preferential pathway of T4 deiodinations, in agreement with the extrathyroidal T3 production rates reported by Klein et al. (1978b). Up to date, few data have been published on neonatal changes in plasma reverse T3 levels in lambs. In the suckling animals, they progressively decreased from birth to $48 \mathrm{~h}$ post partum, in agreement with the partial data of Mathur et al. (1980). Such a profile is detectable from Day 132 of gestation in the lamb foetus (Wrutniak et al., 1985). After birth, the decrease in plasma reverse T3 levels could be related to the drop in the reverse T3 production rate reported by Klein et al. (1978b), in agreement with the sharp decrease in the value of reverse $\mathrm{T} 3 /$ free $\mathrm{T} 4$ ratio.

2) While in suckling lambs free T4 and free and total T3 levels in plasma reached a steady state from $8 \mathrm{~h}$ post partum, in standardized bottle-fed lambs plasma total and free T4 and total and free T3 levels decreased sharply from 8 to $20 \mathrm{~h}$ post partum, whereas reverse T3 levels rose. Moreover, the abrupt changes in the values of $\mathrm{T} 3 /$ free $\mathrm{T} 4$ and reverse $\mathrm{T} 3 /$ free $\mathrm{T} 4$ ratios suggest strong modifications in peripheral T4 deiodinations and/or in T3 or reverse T3 utilization in standardized bottle-fed lambs. Work is in progress to determine whether these particular changes are linked to neonatal hypotrophy or undernutrition.

In conclusion, although free T3 levels are closely related to total T3 levels during the neonatal period, some differences appear between total and free T4 levels. Particularly, our results indicate that the value of the ratio free T4/total T4 increases during the first hours of life. Consequently, the enhancement of T4 availability for T3 generating cells could partly explain the neonatal surge of T3. Lastly, neonatal hypotrophy or undernutrition could affect neonatal changes in plasma iodothyronine levels.

Reçu en janvier 1986.

Accepté en septembre 1986.

Acknowledgements. - The authors wish to thank Mrs Christiane Foucher for her invaluable technical assistance and Mrs Marylee Rambaud for revision of the manuscript.

Résumé. Evolution néonatale des taux plasmatiques d'iodothyronines totales et libres chez l'agneau. Considérations physiologiques.

L'évolution néonatale des taux plasmatiques d'iodothyronines totales et libres a été étudiée chez 18 agneaux Limousin $\times$ Romanov qui têtaient la mère (expérience 1) ou chez 24 agneaux de même race nourris au biberon dans des conditions standardisées. Dans ces deux expériences, les taux plasmatiques de T3 libre sont en relation étroite avec ceux de T3 totale, alors que des différences significatives ont pu être observées dans les évolutions comparées de la T4 totale et libre. En particulier, l'augmentation néonatale de la thyroxinémie libre est plus importante que celle de la thyroxinémie totale. L'accroissement, qui en résulte, de la quantité de T4 utilisable par les cellules pour la production de T3, pourrait expliquer, au moins en partie, l'élévation néonatale de la triiodothyroninémie. De plus, les taux plasmatiques de T3 inverse diminuent progressivement au cours des premières $48 \mathrm{~h}$ chez les agneaux sous la mère. Les résultats présents suggèrent également que l'hypotro- 
phie et/ou la sous-nutrition pourraient modifier la fonction thyroïdienne néonatale : les taux plasmatiques d'iodothyronines actives diminuent fortement chez les agneaux nourris au biberon, alors que la triiodothyroninémie inverse est augmentée.

\section{References}

CABELLO G., LEVIEUX D., 1980. Neonatal changes in the concentrations of thyrotropin, triiodothyronine, thyroxine and cortisol in the plasma of preterm and full-term lambs. $J$. Develop. Physiol., 2, 59-69.

CABELLO G., LEVIEUX D., 1981. Hormonal status in the newborn lamb (cortisol, T3, T4). Relationships to the birth weight and the length of gestation: effect of the litter size. Biol. Neonate, 39, 208-216.

CABELLO G., WRUTNIAK C., 1984. Fonction thyroïdienne fotale et néonatale chez le Ruminant : importance physiologique, 255-274. In JARRIGE R., Physiologie et pathologie périnatales chez les animaux de ferme, INRA Paris.

FISHER D. A., DUSSAULT J. H., SACK J., CHOPRA I. J., 1977. Ontogenesis of hypothalamicpituitary-thyroid function and metabolism in man, sheep and rat. Rec. Progr. Horm. Res., 33, 59-116.

GREER M. A., GRIMM I. M., STUDER H., 1968. Qualitatives changes in the secretion of the thyroid hormones induced by iodine deficiency. Endocrinology, 83, 1193-1196.

KLEIN A. H., ODDIE T. H., FISHER D. A., 1978a. Effect of parturition on serum iodothyronine concentrations in fetal sheep. Endocrinology, 103, 1453-1457.

KLEIN A. H., PADGETT D., CALVARIO G., ODDIE T. H., FISHER D. A., 1978b. Ontogenesis of iodothyronine production and clearence in sheep. Clin. Res., 26, 170A.

MATHUR H., BROWN B. L., KRANE E. J., THOMAS A. L., NATHANIELSZ P. W., 1980. Thyroid hormone relationships in the fetal and newborn lamb. Biol. Neonate, 37, 138-144.

NATHANIELSZ P. W., FISHER D. A., 1979. Thyroid function in the perinatal period. An. Reprod. Sci, 2, 57-62.

NATHANIELSZ P. W., SILVER M., COMLINE R. S., 1973. Plasma triiodothyronine concentration in the foetal and newborn lamb. J. Endocr., 58, 683-684.

SACK J., BEAUDRY M. A., DELAMATER P. V., OH W., FISHER D. A., 1974. The mechanisms of neonatal thyroidal hyperactivity in the newborn sheep. Pediatr. Res., 8, 374.

SACK J., BEAUDRY M., DELAMATER P., OH W., FISHER D. A., 1975. The mechanism of the T3 response to parturition. Pediatr. Res., 9, 682.

SACK J., FISHER D. A., 1975. TSH metabolism in the newborn lamb. Pediatr. Res., 9. 674.

WRUTNIAK C., 1985. Mise en évidence d'anomalies de la fonction thyrödienne néonatale chez l'agneau hypotrophique. Origine et conséquences physiologiques. Thèse de $3^{3}$ cycle $N^{\circ} 815$, Université de Clermont II, 98 pages.

WRUTNIAK C., CABELLO G., 1985. Endocrine activity in preterm and full-term lambs. 1. - Adrenal response to synacthen. 2. - Thyroid response to ovine thyroid-stimulating hormone or thyrotropin-releasing hormone. Biol. Neonate, 47, 280-287.

WRUTNIAK C., CABELLO G., 1986. Influence d'une restriction alimentaire sur la fonction thyroïdienne de l'agneau nouveau-né. J. Physiol. (Paris), 80 (Abstr.).

WRUTNIAK C., CABELLO G., BOSC M., 1985. Plasma free and total iodothyronines levels in hypophysectomized or intact lamb foetuses during the last third of gestation. Acta endocrinol., 110, 388-394. 